\title{
In-vitro Assessment of Heavy Metal Removal from Contaminated Agricultural Soil by Native Plant Species
}

\author{
Shazia Akhtar* and Shazia Iram \\ Fatima Jinnah Women University, The Mall, Rawalpindi, Pakistan. \\ *Corresponding Author Email: shazoo_786@yahoo.com \\ Received 07 September 2016, Revised 22 November 2017, Accepted 01 December 2017
}

\begin{abstract}
Soil pollution by toxic metals such as cadmium $(\mathrm{Cd})$, lead $(\mathrm{Pb})$, chromium $(\mathrm{Cr})$ and copper $(\mathrm{Cu})$ is a major problem in different agricultural areas of Pakistan especially Gujranwala and Lahore. The objective of this study was to assess the accumulation and uptake of toxic metals from contaminated soil by using local plants such as Soybean (Glycine max), Barley (Hordeum vulgare), Sunflower (Helianthus annuus), Pearl millet (Pennisetum americanum), Maize (Zea mays), Canola (Brassica napus) and Wheat (Triticum aestivum). This study was based on the comparison of heavy metal concentrations and their accumulation in different parts of plants. Invitro experiments were conducted by collecting soil from peri-urban areas of Gujranwala and Lahore being irrigated with untreated wastewater. Different seed varieties of local plants were brought from sale shop at National Agriculture Research Center (NARC) Islamabad. Seeds were germinated and grown in laboratory in ambient environment. Plants were irrigated with different levels of each toxic metal and a control was also run. Plant samples were harvested on $20^{\text {th }}$ day and heavy metal concentrations were checked in roots and shoots of plants. Accumulation of heavy metals in the shoots and roots of local plants was measured using Flame Atomic Absorption Spectrophotometer (FAAS). The evidences provided by this experiment indicated that native crops like maize and canola were effective for phytoremediation of toxic metal polluted soil. In the future further experiments should be performed in order to investigate the phytoremediation potential of these crops for metals.
\end{abstract}

Keywords: Heavy metals, Native crops, Phytoremediation, Soil.

\section{Introduction}

Heavy metals are natural constituents of earth crust and they are generally found in low concentration. Anthropogenic activities have also increased metals concentration in the environment [1]. Due to rapid growth of population, industrialization, urbanization and increased agricultural practices environmental pollution is also raising. Since 1900 heavy metals pollution has increased sharply [2]. These heavy metals are difficult to destroy biologically however they can be transformed from highly toxic form to less toxic form [3]. Some heavy metals are essential for global ecosystem. These metals exist in the environment with different oxidation states and their oxidation number is related to their toxicity. These heavy metals are ultimately derived from different sources and affecting the whole ecosystem [4]. In Pakistan like other developing countries laws enforcement regarding industrial waste disposal is ineffective and a large number of industries dump their waste into fresh water, which in turn is responsible for soil pollution [5]. Industrial waste contain high concentrations of heavy metals, when added to water bodies and dispersed in irrigation water caused serious type of environmental pollution, causing bad effects on whole biota and ultimately causing a threat to the human being [6]. Parsad and Parsad [7] reported that heavy metals accumulation in nutrient solution and soil results in impaired metabolism and growth retardation in 
plants. Pakistan peri-urban agricultural soils often received contaminated waste water, polluted or loaded with toxic heavy metals [8].

Some heavy metals are biologically essential even then in excess they become toxic strongly, such type of metals pollution causes inhibition of plants growth and it is highly toxic to plants cells and cause death [9]. McGrath et al., [10] reported that high metals concentration in soil can decrease microbial activities, fertility of soil and also crop yield. Steffens [11] described that near mining operations, landfill or waste disposal sites, on some agricultural sites and natural soil sites plant toxic and lethal metals levels were experienced.

In Pakistan, the use of plant species to decontaminate and remediate polluted soils with heavy metals is very scarce and limited. In Pakistan, study area Gujranwala is also receiving industrial and domestic waste water as an irrigation source. Rhoades [12] has suggested effective species mustard (Brassica juncea L.) has potential of concentrating Se in shoots. Some researches has depicted that Thlaspi caerulescens can accumulate $\mathrm{Cd}$ in shoots [13]. Similarly Berkheya coddii can hyper accumulate $\mathrm{Ni}$ and have ability to reclamate moderately polluted soil with two crops [14]. Sunflower can also be used for metals polluted soils [15]. Due to high biomass production of sunflower it can be used for phytoextraction process. This study was planned to check the root shoot biomass production and heavy metals uptake by native plants species in metals contaminated soils in laboratory.

\section{Materials and Methods Soil selection and preparation}

Metals contaminated soil samples of Gujranwala were selected for further experimentation. This soil was selected due to higher level of contamination and bulk sample was taken for the experiments. The soil was airdried on open air, grinded and sieved through a 2-mm sieve for further experimentation.

\section{Seed germination}

Seeds of native plants (vegetable and crops) of Gujranwala were surface sterilized in
$1.5 \%$ sodium hypochlorite for 5 minutes then washed thoroughly with distilled water (Gupta, 2003). Then seeds were placed on filter paper in Petri dishes containing $20 \mathrm{~mL}$ distilled water for 48 hours. Every plant seeds were sown in triplicate under laboratory conditions. Seeds were considered germinated when their radical was at least $2 \mathrm{~mm}$ out.

\section{Plant growth}

After germination plants were shifted in plastic cups having 75 grams soil and allowed to grow in-vitro under condition of constant amounts of water dissolved urea and sulphate of potash (SOP). On $20^{\text {th }}$ day plant samples were analyzed for heavy metal concentrations because they received maximum heavy metals in the soluble form and had large biomass production. Both shoot and root portions of plant samples were processed for total heavy metal analysis [16]. All the collected plant samples were washed thoroughly under running tap water and distilled water so that no soil particles remained, air dried and then oven dried at $70^{\circ} \mathrm{C}$ for 10 hours. After that dried roots and shoots were grinded separately with pestle and mortar. The grinded plant samples $(0.25 \mathrm{~g})$ were added in $10 \mathrm{~mL}$ of double acid $\mathrm{HNO}_{3}: \mathrm{HClO}_{4}(2: 1$ ratio) in conical flask $(100 \mathrm{~mL})$ and placed on hot plate in fume hood at $250^{\circ} \mathrm{C}$. After 3 hours plant samples were digested and all samples were filtered and diluted up to $15 \mathrm{~mL}$ [16]. Filtered samples were analyzed for heavy metals $\mathrm{Cu}, \mathrm{Pb}, \mathrm{Cd}$, and $\mathrm{Cr}$. For quantification, stock solutions were prepared using salts of corresponding metal ions; $\mathrm{CuSO}_{4}$, $\mathrm{Pb}\left(\mathrm{NO}_{3}\right)_{2}, \mathrm{Cd}\left(\mathrm{NO}_{3}\right)_{2}$ and $\mathrm{Cr}\left(\mathrm{NO}_{3}\right)_{3}$ of analytical grade supplied by Merck and Sigma Aldrich. Concentration $(0.5-4 \mu \mathrm{g} / \mathrm{mL})$ vs absorbance calibration graph were constructed by running various concentrations of each metal ion on Flame Atomic Absorption Spectrophotometer using air-acetylene as flame (PerkinElmer Analyser 800 model). Regression (R) values were in the range of 0.997-0.999.

\section{Results and Discussion}

Present study consisted of laboratory experiments in which the ability of local plants to uptake and accumulate toxic metals from the 
contaminated soils of Gujranwala and Lahore was checked. Seeds of Wheat (Triticum aestivum), Soybean (Glycine max), Barley (Hordeum vulgare), Sunflower (Helianthus annuus), Pearl millet or Pearl millet (Pennisetum americanum), Maize (Zea mays) and Mustard (Brassica campesstris) were grown in-vitro.

\section{Growth of native plant roots and shoots}

Shoot length of native plants is presented in (Table 1). Maximum shoot length was shown by barely crop at $150 \mathrm{mg} \mathrm{kg}^{-1}$. On the other hand minimum shoot length was shown by mustard crop. The order of shoot length of remaining crops was wheat, maize, pearl millet, sunflower and soyabean. Maximum shoot length of wheat $(12 \mathrm{~cm})$ was noticed at $50 \mathrm{mg} \mathrm{kg}^{-1}$ of $\mathrm{Cu}$ concentration. In case of barely shoot length was almost similar at 0 , 50 and $150 \mathrm{mg} \mathrm{kg}^{-1}$ concentration of $\mathrm{Cu}$, but length reduced at $250 \mathrm{mg} \mathrm{kg}^{-1}$. It was shown that $\mathrm{Cu}$ application enhanced barely growth at lowest concentration and become toxic at higher concentration $\left(250 \mathrm{mg} \mathrm{kg}^{-1}\right)$. By growing maize crop in laboratory, it was observed that control pot showed more shoot growth than $\mathrm{Cu}$ applied pots $\left(50,150\right.$ and $\left.250 \mathrm{mg} \mathrm{kg}^{-1}\right)$. Minimum growth was noticed at $250 \mathrm{mg} \mathrm{kg}^{-1}$ which was $1.1 \mathrm{~cm}$. Maximum shoot length of pearl millet $(20.60 \mathrm{~cm})$ was noticed at $150 \mathrm{~m}$.

Maximum root length was shown by barely crop then mazie, pearl millet, wheat, sunflower, soyabean and mustard. Wheat root length was observed maximum $(7.6 \mathrm{~cm})$ at $50 \mathrm{mg}$ $\mathrm{kg}^{-1}$ concentration of $\mathrm{Cu}$ and then the length was reduced when concentration was increased. Maximum barely root length was observed at control. Maximum maize growth was observed at $\mathrm{mg} \mathrm{kg}{ }^{-1}$. Similar was the case of sunflower and pearl millet. However mustard and soybean growth was enhanced at $50 \mathrm{mg} \mathrm{kg}^{-1}$ (Table 2).

In the present study mustard root and shoot lengths and their fresh and dry weights were decreased with the treatment of higher $\mathrm{Cu}$, $\mathrm{Cd}, \mathrm{Pb}$ and $\mathrm{Cr}$. This finding is supported from the results of Turan and Esringü [17] that adverse effects of $\mathrm{Cu}$ on roots are related to severe reduction in the elongation growth of the longest root as well as root plasma membrane permeability of the seedlings.

Table 1. Effect of different concentrations of metals on native plants shoots length.

\begin{tabular}{|c|c|c|c|c|c|}
\hline \multirow{2}{*}{ Native Crops } & \multirow{2}{*}{$\begin{array}{c}\text { Metals } \\
\mathrm{mg} \mathrm{kg}^{-1}\end{array}$} & \multicolumn{4}{|c|}{ Shoot length $(\mathrm{cm})$} \\
\hline & & $\mathrm{Cu}$ & $C d$ & $\mathrm{Cr}$ & $P b$ \\
\hline \multirow[t]{4}{*}{ Wheat } & Control & 10.8 & 21.8 & 7.2 & 16.0 \\
\hline & 50 & 12.0 & 21.2 & 19.2 & 15.4 \\
\hline & 150 & 9.3 & 18.2 & 10.2 & 20.7 \\
\hline & 250 & 7.7 & 0.0 & 2.2 & 1.3 \\
\hline \multirow[t]{4}{*}{ Barely } & Control & 22.2 & 19.4 & 21.7 & 20.0 \\
\hline & 50 & 22.2 & 17.0 & 17.3 & 20.7 \\
\hline & 150 & 22.1 & 22.8 & 20.7 & 20.2 \\
\hline & 250 & 18.6 & 16.3 & 21.0 & 19.9 \\
\hline \multirow[t]{4}{*}{ Maize } & Control & 10.0 & 0.0 & 16.6 & 25.3 \\
\hline & 50 & 6.6 & 27.2 & 14.2 & 14.0 \\
\hline & 150 & 3.6 & 24.8 & 4.1 & 26.0 \\
\hline & 250 & 1.1 & 19.4 & 1.0 & 9.1 \\
\hline \multirow[t]{4}{*}{ Sunflower } & Control & 5.4 & 4.7 & 9.0 & 14.5 \\
\hline & 50 & 2.6 & 4.6 & 6.5 & 13.1 \\
\hline & 150 & 2.9 & 3.9 & 1.4 & 7.0 \\
\hline & 250 & 1.5 & 0.3 & 1.3 & 13.4 \\
\hline \multirow[t]{4}{*}{ Pearl millet } & Control & 15.6 & 15.6 & 2.9 & 5.9 \\
\hline & 50 & 16.2 & 14.4 & 7.4 & 7.2 \\
\hline & 150 & 20.1 & 7.7 & 6.4 & 5.4 \\
\hline & 250 & 10.2 & 5.7 & 10.6 & 6.9 \\
\hline \multirow[t]{4}{*}{ Mustard } & Control & 2.3 & 0.7 & 2.9 & 3.8 \\
\hline & 50 & 3.5 & 4.1 & 3.0 & 2.2 \\
\hline & 150 & 3.4 & 1.1 & 2.6 & 1.7 \\
\hline & 250 & 6.7 & 1.4 & 2.0 & 1.4 \\
\hline \multirow[t]{4}{*}{ Soyabean } & Control & 5.0 & 1.7 & 9.8 & 3.3 \\
\hline & 50 & 3.6 & 3.5 & 8.9 & 1.3 \\
\hline & 150 & 3.5 & 2.0 & 8.1 & 1.7 \\
\hline & 250 & 3.4 & 0.0 & 0.4 & 1.0 \\
\hline
\end{tabular}

Table 2. Effect of different concentrations of metals on native plants roots length.

\begin{tabular}{|c|c|c|c|c|c|}
\hline \multirow{2}{*}{ Native Crops } & \multirow{2}{*}{$\begin{array}{l}\text { Metals } \\
\text { mg kg }^{-1}\end{array}$} & \multicolumn{4}{|c|}{ Root length (cm) } \\
\hline & & $C u$ & $C d$ & $\mathrm{Cr}$ & $P b$ \\
\hline \multirow[t]{4}{*}{ Wheat } & Control & 7.3 & 7.8 & 2.4 & 14.9 \\
\hline & $\mathbf{5 0}$ & 7.6 & 7.3 & 7.2 & 12.3 \\
\hline & 150 & 5.4 & 10.8 & 4.7 & 8.2 \\
\hline & 250 & 6.6 & 0.0 & 0.4 & 0.0 \\
\hline \multirow[t]{4}{*}{ Soyabean } & Control & 3.8 & 1.0 & 7.0 & 3.1 \\
\hline & $\mathbf{5 0}$ & 2.8 & 3.9 & 5.3 & 0.9 \\
\hline & 150 & 2.1 & 1.3 & 6.5 & 2.3 \\
\hline & 250 & 2.8 & 0.0 & 1.1 & 1.2 \\
\hline \multirow[t]{4}{*}{ Barely } & Control & 18.4 & 5.2 & 12.4 & 9.7 \\
\hline & $\mathbf{5 0}$ & 16.1 & 6.0 & 9.0 & 13.3 \\
\hline & 150 & 17.1 & 5.3 & 10.1 & 10.7 \\
\hline & 250 & 16.8 & 3.5 & 10.9 & 10.2 \\
\hline \multirow[t]{4}{*}{ Sunflower } & Control & 13.3 & 3.8 & 10.3 & 9.7 \\
\hline & $\mathbf{5 0}$ & 4.3 & 4.7 & 9.1 & 9.3 \\
\hline & 150 & 9.0 & 3.6 & 0.5 & 8.2 \\
\hline & 250 & 4.0 & 0.0 & 2.2 & 9.6 \\
\hline \multirow[t]{4}{*}{ Pearl millet } & Control & 17.0 & 9.3 & 5.0 & 7.7 \\
\hline & $\mathbf{5 0}$ & 11.1 & 8.1 & 1.5 & 6.0 \\
\hline & 150 & 17.2 & 8.7 & 1.8 & 6.0 \\
\hline & 250 & 12.6 & 6.7 & 3.4 & 7.7 \\
\hline \multirow[t]{4}{*}{ Maize } & Control & 10.8 & & 8.3 & 20.6 \\
\hline & $\mathbf{5 0}$ & 11.5 & 8.6 & 8.0 & 8.5 \\
\hline & 150 & 7.4 & 14.0 & 2.5 & 16.0 \\
\hline & 250 & 2.9 & 12.7 & 1.0 & 6.9 \\
\hline \multirow[t]{4}{*}{ Mustard } & Control & 0.6 & 0.3 & 4.6 & 4.5 \\
\hline & 50 & 3.8 & 4.7 & 1.3 & 2.3 \\
\hline & 150 & 3.7 & 0.6 & 1.4 & 0.7 \\
\hline & 250 & 4.0 & 0.2 & 0.6 & 0.1 \\
\hline
\end{tabular}




\section{Effect of heavy metals on growth of native plant}

Effect of $\mathrm{Cu}, \mathrm{Cd}, \mathrm{Cr}$ and $\mathrm{Pb}$ concentrations on the biomass of wheat, barely, maize, sunflower, pearl millet, mustard and soybean, in terms of fresh and dry weight were investigated (shoot fresh biomass of all seven crops tested in-vitro till $20^{\text {th }}$ day of their growth was included in the study). It was revealed from the results that maximum shoot biomass of wheat $(0.122 \mathrm{~g})$ was at $50 \mathrm{mg} \mathrm{kg}^{-1}$ of $\mathrm{Cu}$ concentration. $\mathrm{Cd}$ contaminated soil of Gujranwala showed maximum wheat shoot biomass at control level $(0.329 \mathrm{~g})$ after this level with increasing $\mathrm{Cd}$ doses wheat shoot biomass reduced sequentially. Maximum wheat shoot biomass was observed at $50 \mathrm{mg} \mathrm{kg}^{-1}$ of Cr level and $\mathrm{Pb}$ polluted soil showed maximum shoot biomass at $150 \mathrm{mg} \mathrm{kg}^{-1}$ of $\mathrm{Pb}$ level and biomass decreased at $250 \mathrm{mg} \mathrm{kg}^{-1}$. Dry biomass of wheat shoot showed behaviour corrosponding to fresh shoots weight.

The seed germination of wheat in copper was extremely slow as tiny radicals appeared on $6^{\text {th }}$ day this shows that $\mathrm{Cu}$ exerted the adverse effects on seed germination similar results were found in the other studies [18]. In case of sunflower shoots the uptake and accumulation process with changing concentration of $\mathrm{Pb}$ was high which indicated greater potential of sunflower to store $\mathrm{Pb}$ in roots.

Barely crop was grown in contaminated soils of Gujranwala and it was shown that barely fresh shoots showed maximum biomass $(0.119$, 0.245 and $0.108 \mathrm{~g}$ ) at $150 \mathrm{mg} \mathrm{kg}^{-1}$ of $\mathrm{Cu}, \mathrm{Cr}$ and $\mathrm{Pb}$ respectively. This was optimum level for three metals to obtain maximum barely shoot biomass. However in $\mathrm{Cr}$ contaminated soil maximum fresh shoot biomass was noticed at control level and with increasing concentration biomass decreased. So, the overall analysis results revealed maximum biomass at control and it was decreased when concentrations of metals were increased. Barley growth was significant in almost all concentrations of heavy metals. In $\mathrm{Cu}, \mathrm{Cr}$ and $\mathrm{Pb}$ the growth of barley shoots and roots was higher than control plants as well as crops. It was noticed that inhibitory effect of $\mathrm{Cu}$ and $\mathrm{Pb}$ on seed germination shoots and roots growth was very low on barley as compared to other crops.
Maize fresh shoot biomass was obtained by growing it in metals contaminated soils of Gujranwala. Maximum maize shoot biomass was obtained $(1.79,0.56$ and $3.15 \mathrm{~g})$ at $50 \mathrm{mg} \mathrm{kg}^{-1}$ of $\mathrm{Cu}, \mathrm{Cd}$ and $\mathrm{Pb}$ concentrations, respectivly. These results showed that maize shoot biomass could be produced maximum at $50 \mathrm{mg} \mathrm{kg}^{-1}$ of $\mathrm{Cu}, \mathrm{Cd}$ and $\mathrm{Pb}$. $\mathrm{Cr}$ showed more toxicity for the maize shoots. Maximum biomass was showed at control $(1.11 \mathrm{~g})$ and at 50,150 and $250 \mathrm{mg} \mathrm{kg}^{-1}$ of Cr. Minimum maize shoot biomass was obtained $1.1 \mathrm{~g}$ at $250 \mathrm{mg}$ $\mathrm{kg}^{-1}$. Dry shoot biomass also showed similar trend. Sunflower was another native crop grown in contaminated soils of Gujranwala and it was shown that sunflower fresh shoots showed maximum biomass $(0.625,0.303,0.632$ and 0.699 g) at $0,50 \mathrm{mg} \mathrm{kg}^{-1}$ of $\mathrm{Cu}, \mathrm{Cd}, \mathrm{Cr}$ and $\mathrm{Pb}$, respectively. $\mathrm{Cu}$ and $\mathrm{Cr}$ were more toxic for sunflower as with increasing metals concentrations shoot biomass was decreased. In case of $\mathrm{Pb}$, biomass was slightly reduced at 50 and $150 \mathrm{mg} \mathrm{kg}^{-}$ ${ }^{1}$ of $\mathrm{Pb}$ concentartion but again increased $(0.623 \mathrm{~g})$ at $250 \mathrm{mg} \mathrm{kg}^{-1}$. Dry shoots were also showed biomass production in same pattern.

Pearl millet fresh shoot biomass was obtained by growing it in metals contaminated soils of Gujranwala. It was observed from the results that maximum shoot biomass of pearl millet $(0.102 \mathrm{~g})$ found at $150 \mathrm{mg} \mathrm{kg}{ }^{-1}$ of $\mathrm{Cu}$ concentration. Cd contaminated soil of Gujranwala indicated maximum pearl millet shoot biomass $(0.071 \mathrm{~g})$ at concentration of $50 \mathrm{mg} \mathrm{kg}^{-1}$. After this level, with increase in $\mathrm{Cd}$ doses pearl millet shoot biomass was reduced. Maximum pearl millet shoot biomass was observed at $250 \mathrm{mg} \mathrm{kg}^{-1}$ of $\mathrm{Cr}$ level while $\mathrm{Pb}$ polluted soil showed maximum shoot biomass at 0 and $150 \mathrm{mg} \mathrm{kg}^{-1}$ level and biomass decreased at $250 \mathrm{mg} \mathrm{kg}^{-1}$. Dry biomass of pearl millet shoot showed behaviour corrosponding to fresh shoot weights.

Mustard was another native crop grown in contaminated soils of Gujranwala, mustard fresh shoots showed maximum biomass $(0.623,2.067$, 1.8 and $3.356 \mathrm{~g}$ ) in control pots of $\mathrm{Cu}, \mathrm{Cd}, \mathrm{Cr}$ and $\mathrm{Pb}$ applied soils respectively. Mustard was more effective for $\mathrm{Pb}$ uptake. Overall $250 \mathrm{mg} \mathrm{kg}^{-1}$ dose of all four metals was more toxic to mustard crop. Fresh shoot biomass of soyabean crop in $\mathrm{Cu}$ and 
$\mathrm{Pb}$ contaminated soils was found maximum at control levels. $\mathrm{Cd}$ and $\mathrm{Cr}$ metals showed maximum shoot biomass at $50 \mathrm{mg} \mathrm{kg}^{-1}$ of metals. Dry shoot biomass also depicted similar trend.

Fresh and dry weights of wheat, barley, maize, sunflower, pearl millet, mustard and soyabean grown in $\mathrm{Cu}, \mathrm{Cd}, \mathrm{Cr}$ and $\mathrm{Pb}$ contaminated soils was recorded. These crops were harvested after $20^{\text {th }}$ day of sowing.

Wheat fresh and dry weights were recorded. It was noticed that maximum root fresh biomass in the $\mathrm{Cu}$ contaminated soil was found $0.061 \mathrm{~g}$ at $250 \mathrm{mg} \mathrm{kg}^{-1}$ of $\mathrm{Cu}$ concentration. In case of $\mathrm{Cd}$ application control pots showed more growth of wheat root biomass as compared to other concentrations of $\mathrm{Cd}$. This presented that $\mathrm{Cd}$ was more toxic for wheat root growth. $\mathrm{Cr}$ level of $50 \mathrm{mg} \mathrm{kg}^{-1}$ initially enhanced root growth after this concentration wheat root growth decreased at 150 and $250 \mathrm{mg} \mathrm{kg}^{-1}$. Similarly, in case of $\mathrm{Pb}$ doses maximum wheat growth $(0.086 \mathrm{~g})$ was observed at $150 \mathrm{mg} \mathrm{kg}^{-1}$ of $\mathrm{Pb}$ level and at $250 \mathrm{mg} \mathrm{kg}^{-1}$ concentration wheat root biomass decreased. Similar behavior was observed in case of wheat dry root biomass.

Barley fresh and dry root biomass was measured after in-vitro experiment. It was observed that with increasing $\mathrm{Cu}$ concentration barley fresh roots biomass was increased and maximum biomass was found at $250 \mathrm{mg} \mathrm{kg}^{-1}$ of $\mathrm{Cu}$ concentration. Similar behaviour was depicted by the $\mathrm{Cd}$ and maximum root biomass was observed at $250 \mathrm{mg} \mathrm{kg}^{-1}$ of $\mathrm{Cd}$ concentration $(0.19 \mathrm{~g})$. In case of $\mathrm{Cr}$ application, barley root biomass was slightly decreased from 0 to $50 \mathrm{mg} \mathrm{kg}^{-1}$ of $\mathrm{Cr}$ level (from 0.16 to $0.1 \mathrm{~g}$ ) and then started to increase to 0.13 and 0.25 grams at 150 and $250 \mathrm{mg} \mathrm{kg}^{-1}$ of $\mathrm{Cr}$ respectivly. In contrast to these results $\mathrm{Pb}$ showed different behaviour and maximum root biomass was recorded at control $(0.17 \mathrm{~g})$ and after that it was decreased by increasing concentration of $\mathrm{Pb}$.

Maize was another native crop tested in the laboratory. It was obeserved from the result that maximum maize root biomass was observed at $50 \mathrm{mg} \mathrm{kg}{ }^{-1}$ of $\mathrm{Cu}(0.79 \mathrm{~g})$. Similarly for $\mathrm{Cd}$ maximum maize root biomass was noticed $0.88 \mathrm{~g}$ at $50 \mathrm{mg} \mathrm{kg}^{-1}$ of $\mathrm{Cd}$ level. In case of $\mathrm{Cr}$ control pot showed greater root biomass production ( $0.079 \mathrm{~g}$ ) and with increasing $\mathrm{Cr}$ level maize root biomass was reduced consequently. Similar trend was shown by the $\mathrm{Pb}$ application and maximum root biomass was noticed at control $(0.079 \mathrm{~g})$.

Sunflower fresh roots produced maximum biomass at concentration of $50 \mathrm{mg} \mathrm{kg}^{-1}$ of $\mathrm{Cu}$ (0.16 g). Cd contaminated soils showed similar behaviour and produced maximum root biomass at $50 \mathrm{mg} \mathrm{kg}^{-1}$ of $\mathrm{Cd}$ level but it proved more toxic to sunflower crop and $250 \mathrm{mg} \mathrm{kg}^{-1}$ of $\mathrm{Cd}$ concentration inhibited the sunflower root growth completely. In case of $\mathrm{Cr}$ control pot showed greater root biomass $(0.13 \mathrm{~g})$ and with increasing level of $\mathrm{Cr}$ sunflower roots growth decreased. $\mathrm{Pb}$ contaminated soil showed maximum root biomass (0.159 grams) at $\mathrm{mg} \mathrm{kg}^{-1}$.

Pearl millet fresh and dry root biomass was measured after in-vitro experiment. It was observed that with increase of $\mathrm{Cu}$ concentration pearl millet fresh roots biomass was increased first and reached to maximum at $50 \mathrm{mg} \mathrm{kg}^{-1}$ of $\mathrm{Cu}$ concentration.It was then decreased till $250 \mathrm{mg} \mathrm{kg}^{-}$ ${ }^{1}$ of $\mathrm{Cu}$. In $\mathrm{Cd}$ contaminated soil maximum root biomass was observed at control levelof $\mathrm{Cd}$ concentration $(0.25 \mathrm{~g})$. In case of $\mathrm{Cr}$ application, pearl millet root biomass increased from 0 to 250 $\mathrm{mg} \mathrm{kg}^{-1}$ of $\mathrm{Cr}$ level ( $0.14 \mathrm{~g}$ ). Analogous behaviour was revealed by $\mathrm{Pb}$ and showed maximum root biomass $0.19 \mathrm{~g}$ after that it decreased with increasing $\mathrm{Pb}$ levels.

Mustard root growth enhanced by the addition of $\mathrm{Cu}$ and maximum root biomass was obtained at $250 \mathrm{mg} \mathrm{kg}^{-1}$ of $\mathrm{Cu}$ concentration. $\mathrm{Cd}$ contaminated soil showed greater root biomass production at $50 \mathrm{mg} \mathrm{kg}^{-1}$. In case of $\mathrm{Cr}$ mustard root growth exhibited by the $\mathrm{Cr}$ doses and maximum biomass was observed at $150 \mathrm{mg} \mathrm{kg}^{-1}$ of $\mathrm{Cr}$ concentraion ( $0.8 \mathrm{~g}$ ). $\mathrm{Pb}$ was proved toxic and growth of mustard roots decreased with increasing $\mathrm{Pb}$ levels and control pot showed greater biomass (016 g). Soyabean roots showed greater biomass at control level of $\mathrm{Cu}(0.79 \mathrm{~g})$ then decreased at $50 \mathrm{mg} \mathrm{kg} \mathrm{kg}^{-1} \mathrm{Cu}$ after that a little increase was obsrved but that value was lower than control. $\mathrm{Cd}$ contaminated soil showed maximum root biomass 
0.11 grams at $50 \mathrm{mg} \mathrm{kg}^{-1}$ of $\mathrm{Cd}$. Similar trend was noticed in the case of $\mathrm{Cr}$ and 0.25 grams root biomass was produced at control level. In contrast to this $\mathrm{Pb}$ application enhanced the soyabean growth and maximum biomass was noticed 0.68 grams at $250 \mathrm{mg} \mathrm{kg}^{-1}$ of $\mathrm{Pb}$ concentration.

The uptake and accumulation potential of heavy metals was observed in native plants tissues. The accumulation of heavy metals is dependent on crop type, plant organ i.e. shoots or root and type of heavy metal present in the soil. Plant species differ widely in their ability to uptake and accumulate heavy metals according to [19]. In the present study root and shoot lengths and fresh and dry weights of maize were decreased with the treatment of higher $\mathrm{Cu}, \mathrm{Cd}, \mathrm{Pb}$ and $\mathrm{Cr}$ concentrations respectively. This was in accordance with the finding of Gupta and Abdullah (2011) that root, shoot, seed germination and dry biomasses were decreased when treated with $\mathrm{Cd}$ and $\mathrm{Cu}$ doses of 50, 100, 150 and 200 $\mathrm{mg} \mathrm{L}^{-1}$.

Heavy metals analysis in roots and shoots tissue of wheat indicated that most accumulated metal was $\mathrm{Pb}\left(146.88 \mu \mathrm{g} \mathrm{g}^{-1}\right)$ as compared to other metals. The order of accumulation was $\mathrm{Pb}>\mathrm{Cr}>\mathrm{Cu}>\mathrm{Cd}$. It was also noted that root parts were more efficient in uptake of metals. Maximum $\mathrm{Cr}$ was noticed $115.08 \mathrm{\mu g} \mathrm{g}^{-1}$ in wheat roots; maximum $\mathrm{Cd}$ and $\mathrm{Cu}$ concentration were 86.7 and $107.28 \mu \mathrm{g} \mathrm{g}^{-1}$ in root parts of wheat. In case of $\mathrm{Cd}$, $\mathrm{Cu}$ and $\mathrm{Pb}$ metal uptake by wheat crop increased with increasing their concentrations in soil from 0 to 50,150 and $250 \mathrm{mg} \mathrm{kg}^{-1}$ of soil. Whereas $\mathrm{Cr}$ uptake was maximum at $50 \mathrm{mg} \mathrm{kg}^{-1}$ of soil concentration and decreased at $250 \mathrm{mg} \mathrm{kg}^{-1}$ of soil (Fig. 1).

Barley roots were more efficient in $\mathrm{Cu}$, $\mathrm{Cd}, \mathrm{Cr}$ and $\mathrm{Pb}$ uptake as compared to shoots. Results showed that $\mathrm{Pb}$ was highest accumulated metal by barley crop than $\mathrm{Cu}, \mathrm{Cr}$ and $\mathrm{Cd}$. Fig. 2 depicted that $\mathrm{Cu}, \mathrm{Cd}$ and $\mathrm{Pb}$ removal by barley crop from soil increased with increasing initial metals concentration in soil but $\mathrm{Cr}$ was decreased after $150 \mathrm{mg} \mathrm{kg}^{-1}$ to $250 \mathrm{mg} \mathrm{kg}^{-1}$ of soil. Barley shoot removed maximum $\left(9.48 \mu \mathrm{g} \mathrm{g}^{-1}\right) \mathrm{Cu}$ at control while maximum concentrations of $\mathrm{Cd}$ (54.0 $\left.\mu \mathrm{g} \mathrm{g}^{-1}\right), \mathrm{Cr}\left(11.16 \mu \mathrm{g} \mathrm{g}^{-1}\right)$ and $\mathrm{Pb}\left(115.86 \mu \mathrm{g} \mathrm{g}^{-1}\right)$ was removed at $150 \mathrm{mg} \mathrm{kg}^{-1}$ and $250 \mathrm{mg} \mathrm{kg}^{-1}(\mathrm{Cr}$, $\mathrm{Pb})$ of soil.

The order of metals removal from soil by maize plants was $\mathrm{Cd}>\mathrm{Cr}>\mathrm{Pb}>\mathrm{Cu}$. Among all the levels applied $150 \mathrm{mg} \mathrm{kg}^{-1}$ dose of Cd was optimal level for $\mathrm{Cd}$ removal from soil. Similarly, $\mathrm{Pb}$ and $\mathrm{Cr}$ were removed efficiently at $250 \mathrm{mg} \mathrm{kg}^{-1}$ of soil while $\mathrm{Cu}$ was removed at control and $150 \mathrm{mg} \mathrm{kg}^{-1}$ of soil. By these values it was found out that maize crop was best accumulator for $\mathrm{Cd}$ metal then for $\mathrm{Cr}, \mathrm{Pb}$ and $\mathrm{Cu}$. Maize shoots were more efficient in uptake of $\mathrm{Cu}\left(22.53 \mu \mathrm{g} \mathrm{g}^{-1}\right), \mathrm{Cd}\left(141.93 \mu \mathrm{g} \mathrm{g}^{-1}\right)$ and $\mathrm{Cr}\left(97.02 \mu \mathrm{gg}^{-1}\right)$ while $\mathrm{Pb}\left(69.3 \mu \mathrm{gg}^{-1}\right)$ was highly removed by maize roots (Fig. 3 ).

Copper is also essential to plant growth, but may cause toxic effects when shoots or leaves accumulate $\mathrm{Cu}$ levels exceeding $2 \mathrm{mg} \mathrm{kg}^{-1}$. $\mathrm{Cu}$ play an important role in regulating normal metabolism of plants. At its high concentration $\mathrm{Cu}$ is strongly toxic metal to plants cells and may cause plants growth inhibitor and sometimes cause death of the plant.

Figure 4 depicted that sunflower shoots were good accumulator of $\mathrm{Cd}$ and $\mathrm{Pb}$ whereas higher concentrations of $\mathrm{Cu}$ and $\mathrm{Cr}$ were accumulated by sunflower roots. Maximum $\mathrm{Pb}$ (206.49 $\mu \mathrm{g} \mathrm{g}^{-1}$ ) uptake was noticed in shoots. Maximum Pb (118.68 and $\left.119.76 \mu \mathrm{g} \mathrm{g}^{-1}\right)$ uptake was observed by roots. Sunflower seeds were unable to germinate at $250 \mathrm{mg} \mathrm{kg}^{-1}$ of $\mathrm{Cd}$ concentration in soil and uptake of $\mathrm{Cd}$ at this level was also shown zero. Variable behavior was observed with increasing initial metals concentrations (Fig. 4).

Heavy metals analysis in roots and shoots tissue of pearl millet indicated that most accumulated metal was $\mathrm{Cd}\left(104.4 \mu \mathrm{g} \mathrm{g}^{-1}\right)$ in roots at $250 \mathrm{mg} \mathrm{kg}^{-1}$ as compared to other metals. The order of accumulation was $\mathrm{Cd}>\mathrm{Pb}>\mathrm{Cu}>\mathrm{Cu}>\mathrm{Cr}$. It was also noted that root parts were more efficient in uptake of metals. Maximum $\mathrm{Cr}$ was $11.16 \mu \mathrm{g} \mathrm{g}^{-1}$ in pearl millet roots; maximum $\mathrm{Pb}$ and $\mathrm{Cu}$ concentration were 115.86 and $66.76 \mu \mathrm{g} \mathrm{g} \mathrm{g}^{-1}$ respectively in root parts of pearl millet. In case of $\mathrm{Cd}, \mathrm{Cu}$ and $\mathrm{Cr}$ metals uptake by pearl millet crop 
increased with increasing their concentrations in soil at $0,50,150$ and $250 \mathrm{mg} \mathrm{kg}^{-1}$ of soil. Whereas maximum $\mathrm{Pb}$ removal was observed at $150 \mathrm{mg}$ $\mathrm{kg}^{-1}$ of soil concentration and decreased at $250 \mathrm{mg}$ $\mathrm{kg}^{-1}$ of soil (Fig. 5).

Results obtained from mustard crop at different levels of applied metals showed that $\mathrm{Cu}$, $\mathrm{Cr}$ and $\mathrm{Pb}$ were concentrated more in roots of mustard, while Cd was found high in shoot part of mustard crop. Maximum $\mathrm{Cu}$ concentration was noticed $24.72 \mu \mathrm{g} \mathrm{g}^{-1}$ in roots of mustard. Highest accumulated levels of $\mathrm{Cd}, \mathrm{Cr}$ and $\mathrm{Pb}$ were 39.22, 38.46, and $39.3 \mu \mathrm{g} \mathrm{g}^{-1}$ respectively. $\mathrm{Cu}$ uptake increased with increasing initial applied concentration, however $\mathrm{Cd}$ removal was maximum at $150 \mathrm{mg} \mathrm{kg}^{-1}(\mathrm{Cd})$ and $\mathrm{Cr}$ and $\mathrm{Pb}$ were translocated efficiently at $50 \mathrm{mg} \mathrm{kg}^{-1}$ (Fig. 6).

Figure 7 presented that $\mathrm{Cu}$ and $\mathrm{Pb}$ were accumulated more in root part where as $\mathrm{Cd}$ and $\mathrm{Cr}$ were concentrated more in shoot of soybean. Maximum $\mathrm{Cu}\left(16.62 \mu \mathrm{g} \mathrm{g}^{-1}\right)$ and $\mathrm{Cr}\left(34.83 \mu \mathrm{g} \mathrm{g}^{-1}\right)$ concentrations were recorded at applied concentration of $250 \mathrm{mg} \mathrm{kg}^{-1}$ and $\mathrm{Cd}$ was noticed $34.83 \mu \mathrm{g} \mathrm{g}^{-1}$ at $50 \mathrm{mg} \mathrm{kg}^{-1}$ of soil concentration. Overall $\mathrm{Pb}\left(82.75 \mu \mathrm{g} \mathrm{g}^{-1}\right)$ was observed as highest concentrated metal in soybean crop among all four tested metals. $\mathrm{Cu}, \mathrm{Cr}$ and $\mathrm{Pb}$ uptake was increased with increasing initial metal concentration but $\mathrm{Cd}$ uptake increased firstly at 0 to $50 \mathrm{mg} \mathrm{kg}^{-1}$ of soil then decreased from 150 to $250 \mathrm{mg} \mathrm{kg}^{-1}$ of soil concentrations (Fig. 7). The accumulation and distribution of heavy metals in plants depends on the environmental factors, such as plant species, element species, chemical and bioavailability, redox, $\mathrm{pH}$, cation exchange capacity, dissolved oxygen, temperature and secretion of roots [19]. In the present study maize accumulated greater cadmium and lead in its roots as compared to chromium and copper. It has been reported that cadmium is a highly mobile metal, easily absorbed by the plants through root surface and moves to wood tissue and transfers to upper parts of plants [20].

Among the selected local plants maize and mustard were effective plants for phytoremediation purpose. Maize was best for phytoremediation of $\mathrm{Cd}$ and $\mathrm{Pb}$ polluted soils and canola for phytoremediation of $\mathrm{Cd}$. All the selected plants were more sensitive to cadmium as compared to other metals. Increase in the concentrations of copper, cadmium, lead and chromium brought up changes in most of the growth parameters of plants. Among all metals cadmium affected more the plant seed germination, seedling growth, shoot and root elongation of selected local plants.

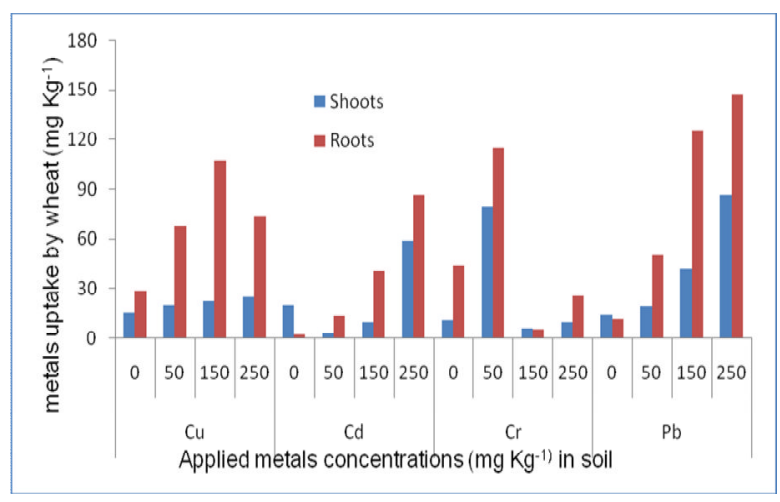

Figure 1. Heavy metals accumulation in shoot and root of wheat

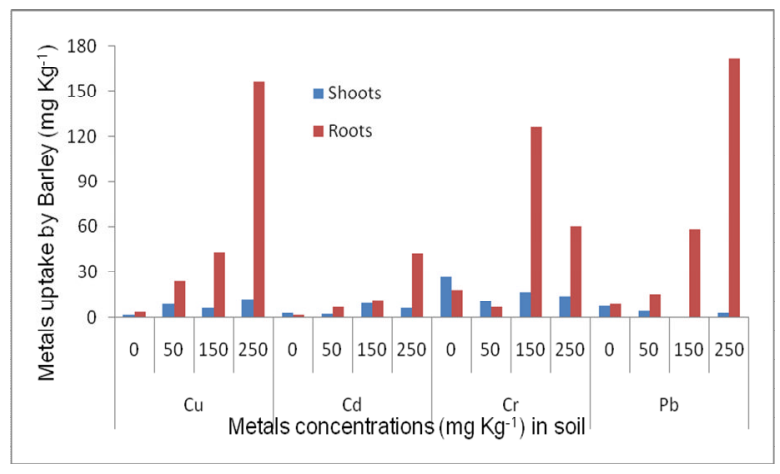

Figure 2. Heavy metals accumulation in shoot and root of Barley

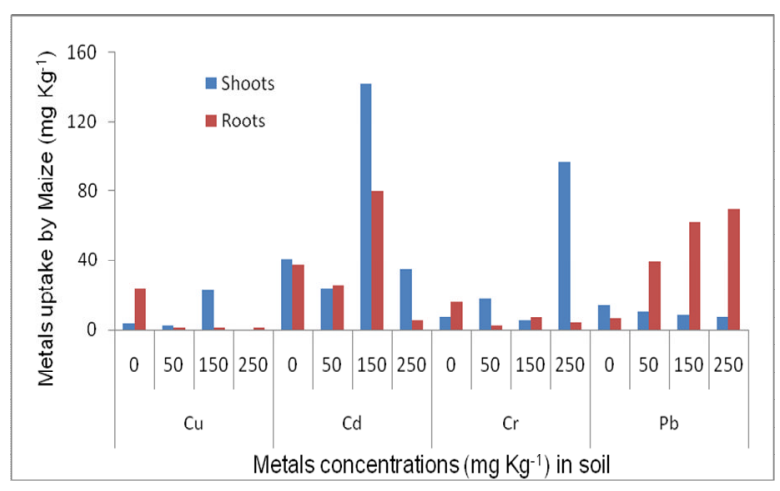

Figure 3. Heavy metals accumulation in shoot and root of Maize 


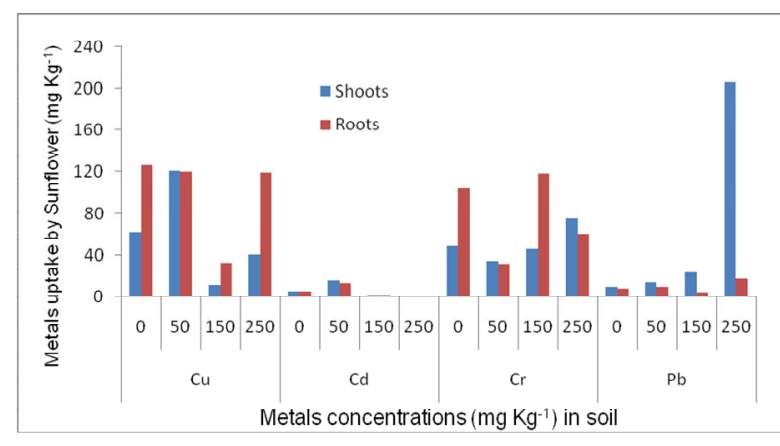

Figure 4. Heavy metals accumulation in shoot and root of Sunflower

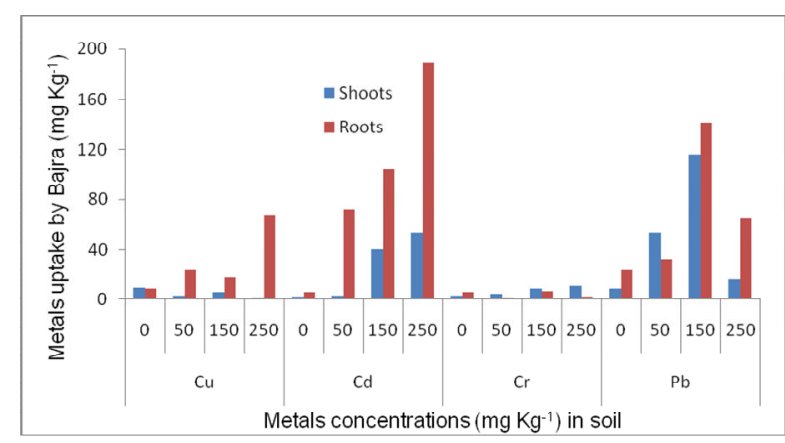

Figure 5. Heavy metals accumulation in shoot and root of Pearl millet

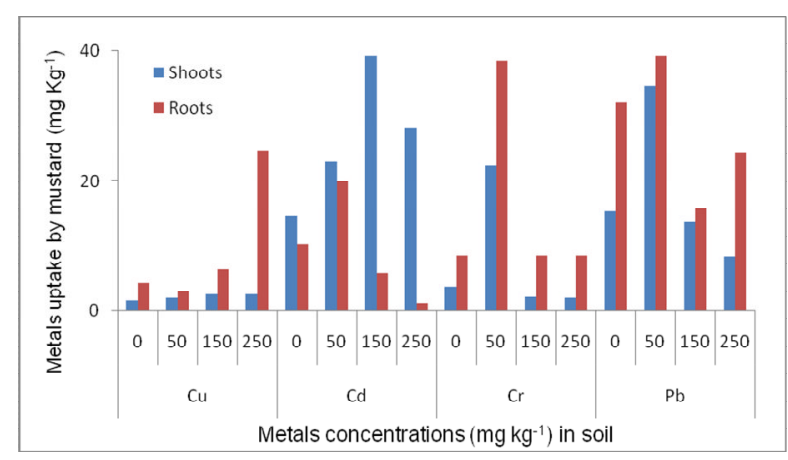

Figure 6. Heavy metals accumulation in shoot and root of mustard

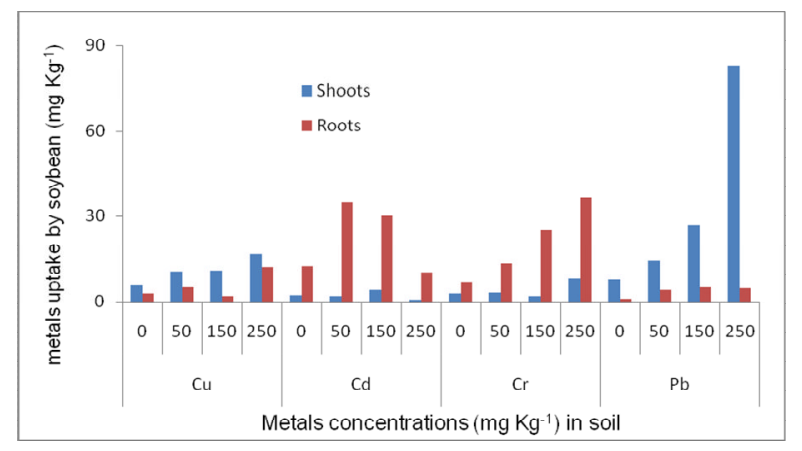

Figure 7. Heavy metals accumulation in shoot and root of Soybean

\section{Conclusion}

In overall study conducted, it is concluded that maize and mustard were more shoot biomass producing crops. Maximum root biomass was produced by barely and pearl millet crops. Maximum shoot and root length was also produced by barley crop. Sunflower and barley were noticed more effective accumulators of $\mathrm{Cu}$. Maize, wheat and barley were proved effective accumulators for $\mathrm{Cd}$ and $\mathrm{Cr}$ accumulation from heavy metals contaminated soils. Phytoremediation can be a good option because different native crops have the ability to accumulate metals e.g maize, mustard, wheat, barley and sunflower etc. Efficient native plants should be grown in the contaminated soil near the industrial areas so that they efficiently phytoremediate the contaminated soils. Crops used in the laboratory experiments (maize, wheat, mustard, canola and sunflower etc.) could be used for multi-tasking like for the management of heavy metals polluted soils (phytoremediation) as well as for biomass production which can be ultimately used for biogas and biofuel production.

\section{References}

1. R. Singh, N. Gautam, A. Mishra and R. Gupta, Indian J. Pharm., 43, (2011). 246.

doi: $10.4103 / 0253-7613.81505$

2. B. D. Ensley, Rational for use of phytoremediation. In: Raskin, I. and Ensley, B. D. eds. Phytoremediation of toxic metals: using plants to clean- up the environment. New York, John Wiley \& Sons, Inc., (2000) 3.

3. C. Garbisu and I. Alkorta. Biores. Technol., 77 (2001) 229.

doi.org/10.1016/S0960-8524 (00)00108-5

4. G. R. MacFarlane and M. D. Burchett, Vierh. Aqu. Bot., 68 (2000) 45. doi:10.1016/S0304-3770(00)00105-4

5. M. A. Khan, Man, Nature and Environment. Research information Section. Ayub Agricultural Research Institute, Faisalabad, (1997).

6. S. M. Ross, Wiley, Chich-ester, (1994) 469. 
7. D. P. H. Prasad and A. R. K. Prasad, Phytochem., 26 (1987) 881.

doi.org/10.1016/S0031-9422(00)82310-9

8. A. Ghafoor, A. Rauf, M. Arif and W. Muzaffar. Pak. J. Agri. Sci., 31 (1995) 37.

9. T. Lanaras M. Moustakas, L. Symeonidis, S. Diamantoglou and S. Karataglis, Physiol. Plant, 88 (1993) 307.

doi.10.1111/j.1399-3054.1993.tb05504.x

10. S. P. McGrath, A. M. Chaudri and K. E. Giller, J. Ind. Microbiol., 14 (1995) 94. doi.org/10.1007/BF01569890

11. J. C. Steffens, Annual Review of Plant Physiology and Plant Molecular Biology, 41 (1990) 553.

doi/10.1146/annurev.pp.41.060190.003005

12. J. D. Rhjoades, Use of saline drainage water for irrigation. In: Skaggs, R. W., Van Schilfgaarde, J. (Eds.) Agricultural Drainage. ASA-CSSA-SSSA, Madison, WI, USA, (1999) 615.

13. R.R. Brooks, M. F. Chambers, L. J. Nicks and B. H. Robinson, Phytomining. Trend Plant Sci., 3 (1998) 359. doi.org/10.1016/S0375-6742 (97)00036-8
14. B. H. Robinson, R. R. Brooks, A. W. Howes, J. H. Kirkman and P. E. H. Gregg, J. Geochem. Explor., 60 (1997) 115. doi.org/10.1016/S0375-6742(97)00036-8

15. E. Nehnevajova, Non-GMO approach for the improvement of heavy metal accumulation and extraction of high yielding crop species for efficient phytoextraction of contaminated soil. Ph. D. Thesis, (2005).

16. I. Ryan, S. Garbert and A. Rashid, A Soil and Plant Analysis manual for the west Asia and North Africa regions. ICARDA, Syria, (2001).

17. M. Turan and A. Esringü, Plant. Soil Env., 53 (2007) 7.

18. P. Kaushik, V. K. Garg and B. Singh, Biores. Tech., 96 (2005) 1189. doi.org/10.1016/j.biortech.2004.09.020

19. S. Cheng, Env. Sc. Poll. Res., 5 (2003) 335.

doi.orq/10.1065/espr2002.11.141.3

20 K. S. Ivana, J. Puncocharova, Z. Kafka, M. Kubal, P. Soudek and T. Vanek, J. Water Air Soil Poll., 3 (2002) 269. 